\title{
Native Subterranean Termites: Reticulitermes flavipes (Kollar), Reticulitermes virginicus (Banks), Reticulitermes hageni Banks (Insecta: Isoptera: Rhinotermitidae) ${ }^{1}$
}

Nan-Yao Su, Rudolf H. Scheffrahn, and Brian Cabrera²

\section{Introduction}

Most pest species of subterranean termites in North America belong to the endemic genus Reticulitermes. Reticulitermes species are found in every state in the continental United States except Alaska, but are most common in the warm and humid southeastern region. The eastern subterranean termite, $R$. flavipes is the most widely distributed and is found in the entire eastern region of North America as far north as Ontario, Canada, and south to Key Largo, Florida. Its counterpart, the western subterranean termite, $R$. hesperus Banks, is found along the entire Pacific Coast ranging from southern California to British Columbia. Reticulitermes tibialis occurs in the inter-mountain region of the West. In addition to $R$. flavipes, two other Reticulitermes occur in Florida, $R$. virginicus, and $R$. hageni.

\section{Description and Identification}

Because of their cryptic nature, structural infestations of subterranean termites are usually not visible. Most people become aware of an infestation when annual flights of winged termites (called alates) occur in structures. The alates of $R$. flavipes and $R$. virginicus are dark brown, while those of $R$. hageni are yellowish brown. Alates of $R$. flavipes are generally larger (approximately 0.4 " long including wings) than those of $R$. virginicus or $R$. hageni (approximately 0.3 " long). Alate wings of Reticulitermes species have two hardened and thickened veins that are visible along the entire front end, but lack the small hairs that are characteristic of the Formosan subterranean termite, Coptotermes formosanus Shiraki. After indoor flights, most alates are found dead near windows or in sinks and bath tubs - usually with their wings still attached.

As with other termite species, Reticulitermes colonies contain three primary castes; the reproductives (king, queen, alates, alate nymphs, and supplementary reproductives), soldiers, and workers. Alates and soldiers are used for species identification.

1. This document is EENY-212, one of a series of Featured Creatures from the Entomology and Nematology Department, Florida Cooperative Extension Service, Institute of Food and Agricultural Sciences, University of Florida. Published: May 2001. This document is also available on Featured Creatures Website at http://creatures.ifas.ufl.edu. Please visit the EDIS Website at http://edis.ifas.ufl.edu. 2. Nan-Yao Su, Rudolf H. Scheffrahn, and Brian Cabrera, Cooperative Extension Service, University of Florida, Ft. Lauderdale, FL.

The Institute of Food and Agricultural Sciences (IFAS) is an Equal Employment Opportunity - Affirmative Action Employer authorized to provide research, educational information and other services only to individuals and institutions that function without regard to race, creed, color, religion, age, disability, sex, sexual orientation, marital status, national origin, political opinions or affiliations. For information on obtaining other extension publications, contact your county Cooperative Extension Service office. Florida Cooperative Extension Service / Institute of Food and Agricultural Sciences / University of Florida / Larry R. Arrington, Interim Dean 


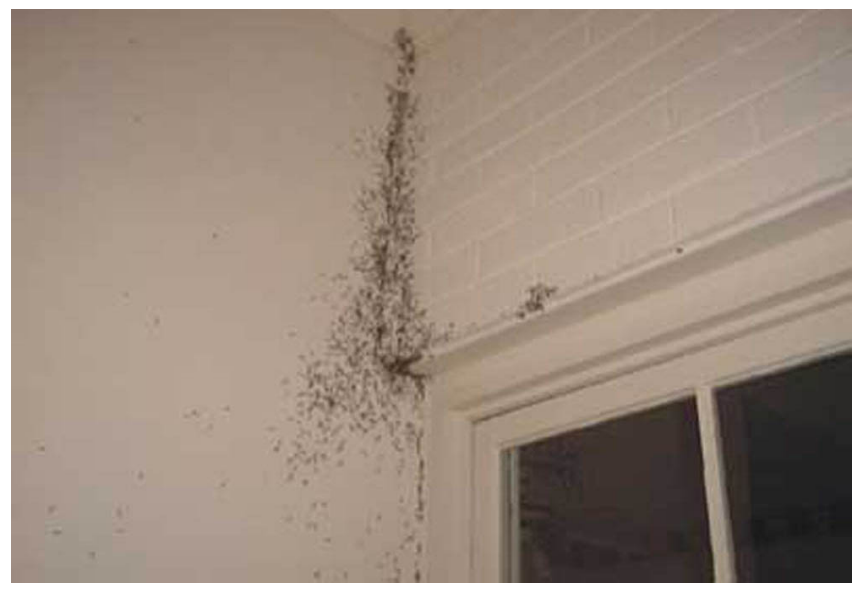

Figure 1. Indoor swarm of eastern subterranean termite, Reticulitermes flavipes (Kollar). Credits: T. Myles, University of Toronto

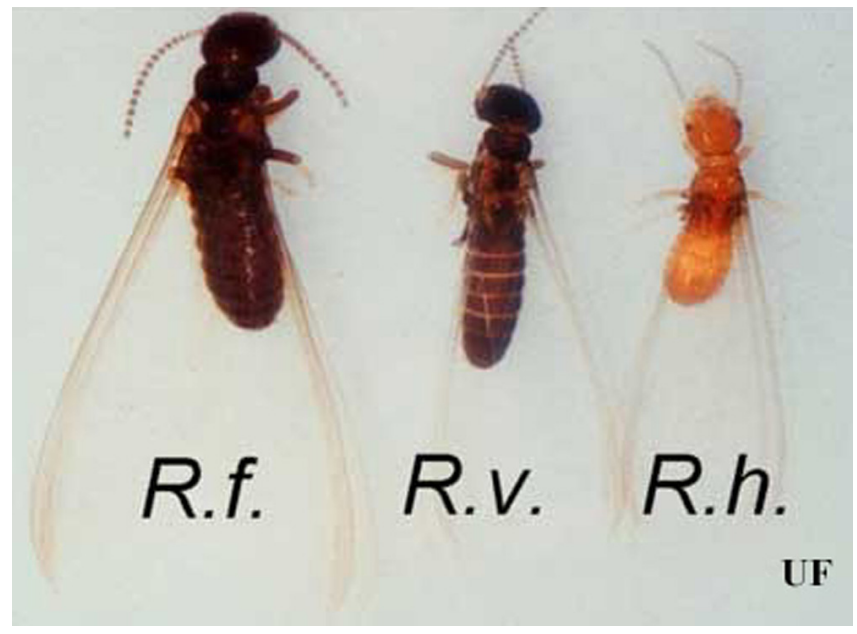

Figure 2. Alates of eastern subterranean termite, Reticulitermes flavipes (Kollar) (R.f.), and other native subterranean termties, $R$. virginicus (Banks) (R.v.) and $R$. hageni Banks (R.h.). Credits: Nan-Yao Su and Rudolf $\mathrm{H}$. Scheffrahn, University of Florida

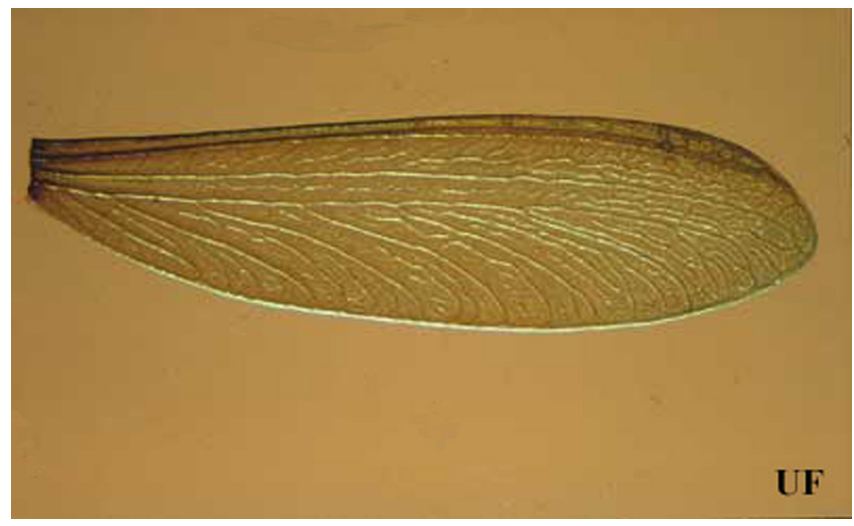

Figure 3. Wing of Reticulitermes, a subterranean termite genus. Credits: Nan-Yao Su and Rudolf H. Scheffrahn, University of Florida

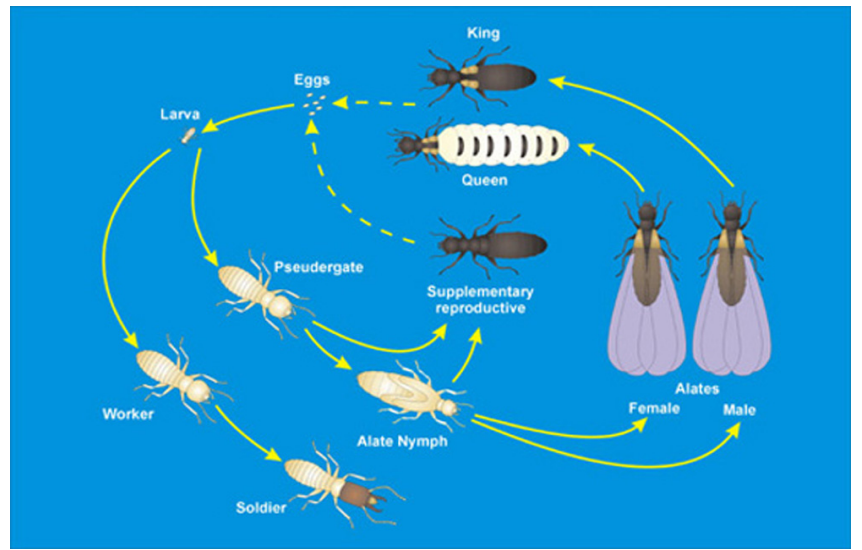

Figure 4. Life cycle of Reticulitermes subterranean species. Credits: Nan-Yao Su and Rudolf H. Scheffrahn, University of Florida

Soldiers of subterranean termites (Rhinotermitidae) are distinguished from those of drywood or dampwood termites (Kalotermitidae) by their smaller size and the relative width of the pronotum. In subterranean termites, the pronotum (segment immediately behind the head) is narrower than the head, while in kalotermidis they are equally as wide. Reticulitermes soldiers are further distinguished from those of $C$. formosanus by the rectangular-shaped head of the former compared to the oval-shaped head of the latter.

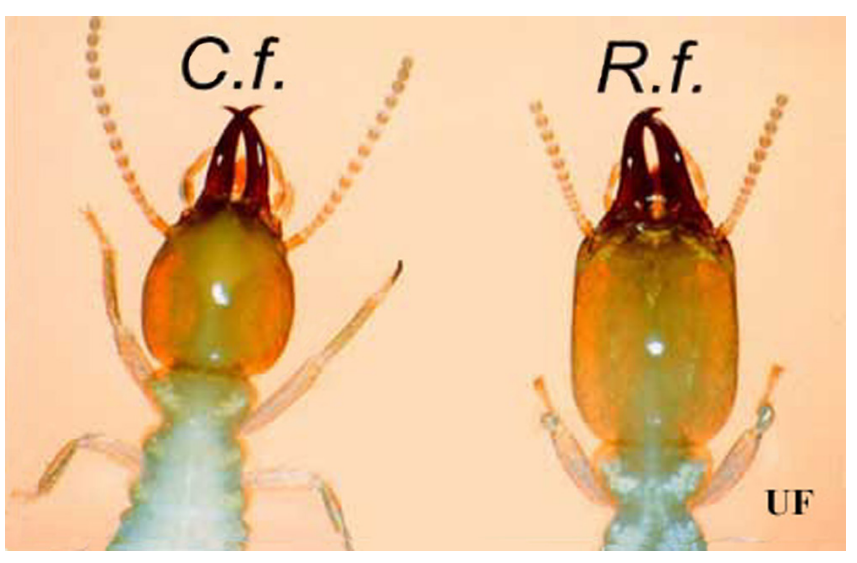

Figure 5. Soldier heads of the Formosan subterranean termite, Coptotermes formosanus (C.f.), and eastern subterranean termites, Reticulitermes flavipes (R.f.). Credits: Nan-Yao Su and Rudolf H. Scheffrahn, University of Florida

Subterranean termites form a network of interconnected feeding sites beneath or above the soil surface. A single colony of subterranean termites, especially those of $R$. flavipes, may contain 100,000 $1,000,000$ termites and forage up to 150 feet in search of food (Su et al. 1993). When subterranean termites 
search for food aboveground, they may enter a house through small cracks or joints in the foundation, or by building shelter tubes along the foundation wall.

These tubes are highways connecting the underground termite population with aboveground food sources.

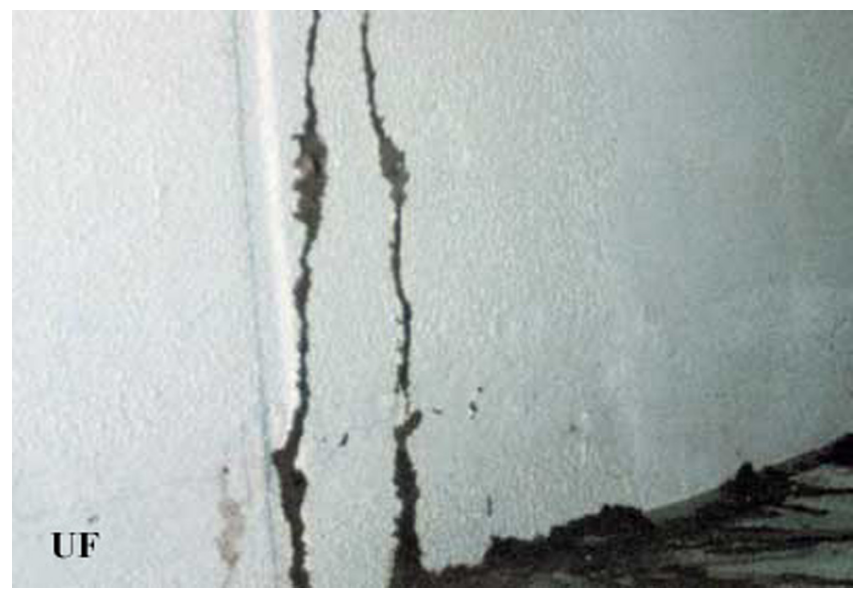

Figure 6. Shelter tubes of Reticulitermes, a subterranean termite genus. Credits: Nan-Yao Su and Rudolf $\mathrm{H}$. Scheffrahn, University of Florida

\section{Life History}

Flight seasons differ among the three Reticulitermes species in Florida. Reticulitermes hageni alate flights begin in early December and last until early February while $R$. flavipes flights start in early January and end in April. Dispersal flights of $R$. virginicus occur between early February and late May. Swarming by $R$. flavipes and $R$. virginicus occurs during warm, sunny and windless afternoons usually after rain, while $R$. hageni alates swarm at night.

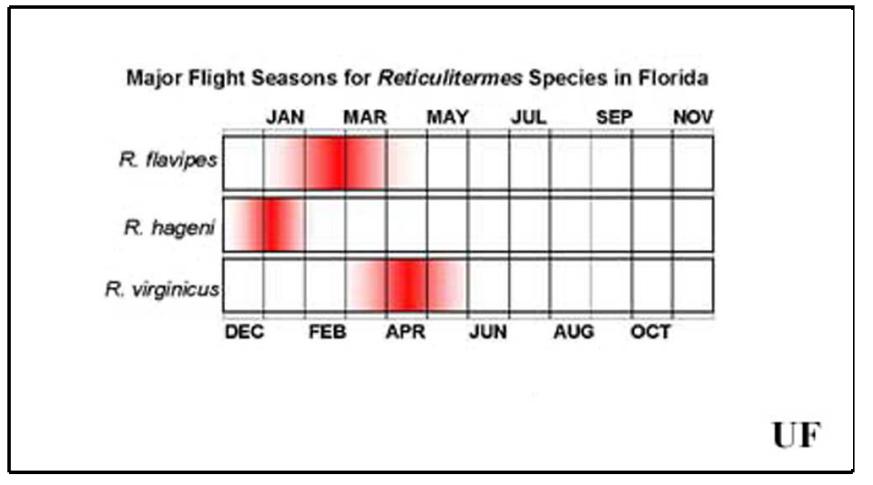

Figure 7. Flight seasons of the three Reticulitermes species in Florida. Credits: Nan-Yao Su and Rudolf $\mathrm{H}$. Scheffrahn, University of Florida
After a brief flight, alates drop to the ground and shed their wings. Females begin to search for potential nesting sites such as moist crevices with wood, and males follow closely behind. The pair forms a royal chamber in a moist site near wood and begin laying eggs, thus starting the life cycle of a subterranean termite colony. Individuals hatched from eggs (called larvae) molt into workers. Some workers may molt into the soldier caste or become alates by molting first into alate nymphs. Some workers or nymphs are capable of becoming supplementary reproductives and take over the role of queen or king if and when a primary reproductive dies or is distanced from part of the colony. It may take five to 10 years for a single pair of alates to form a mature colony that produces alates.

\section{Damage}

Because termites consume cellulose, the main structural components of plant cells, any wood material in a house is a potential food source, but they may also damage non-wood material in search of food. Because termites rarely show themselves in the open, infestations can be difficult to detect until damage becomes severe. In addition to the presence of alates and shelter tubes, wood material can be probed with a screw driver or ice pick to locate infested wood. The surface of severely damaged wood may appear blistered or peeling, as termites hollow out the wood leaving a paper-thin surface. Reticulitermes tend to cover the wood they feed upon with soil, thus giving wood a more "dirty" appearance than $C$. formosanus-infested wood. However, it is not advisable to identify the termite species based solely on damage as there are many exceptions.

\section{Pest Status}

Previously, $R$. flavipes was considered the most common subterranean termite pest of Florida, but our survey indicated that $R$. virginicus is found almost as frequently in structures as $R$. flavipes (Scheffrahn et al. 1988). It is less common to find $R$. hageni infestations. Of the $\$ 2.2$ billon annually spent for termite control in the United States, subterranean termites account for $80 \%$ share, and the majority of this is probably due to $R$. flavipes and $R$. virginicus. 


\section{Management}

\section{Preventive Practice}

Because subterranean termites forage in soil, it is important to keep structural lumber from direct contact with soil. Keeping the lower foundation walls and siding clear of vegetation or mulch makes it easier to inspect for termite shelter tubes.

Subterranean termites need moisture for survival. Leaky plumbing, air conditioning condensate, and any portion of a building and its perimeter that collects excessive amounts of moisture should be corrected to maintain an environment less attractive to subterranean termites. Wood pressure-treated with preservatives such as chromated copper arsenate (CCA) is resistant to termites, and use of treated wood can minimize available food sources for subterranean termites.

\section{Soil Termiticide Barriers}

Spraying the soil beneath the foundation with liquid insecticides has been the traditional method for subterranean termite control. The objective is to place a chemical barrier between termites and the structure to be protected. Before the foundation is poured, soil termiticides are applied onto sub-slab soil to form a horizontal barrier. A vertical barrier is applied around the perimeter after the foundation is poured. This pre-construction treatment is mandatory in many of the United States. Post-construction treatment consists of drilling holes through slabs and injecting insecticides under the foundation and by drenching trenches dug along building foundations. Currently available termiticides include chlorpyrifos (Dursban ${ }^{\circledR}$ TC, Equity ${ }^{\circledR}$, Empire ${ }^{\circledR}$ ), permethrin (Dragnet ${ }^{\circledR}$ FT, Prelude $\left.{ }^{\circledR}\right)$, cypermethrin (Prevail ${ }^{\circledR}$ FT, Demon ${ }^{\circledR}$ TC), bifenthrin (Biflex® FT), fenvalerate (Tribute $\left.{ }^{\circledR}\right)$, imidacloprid (Premise ${ }^{\circledR}$ ), and fipronil (Termidor ${ }^{\circledR}$ ). Pyrethroids such as permethrin, cypermethrin, bifenthrin, and fenvalerate repel termites from treatment barriers, while other termiticides prevent termite invasion by lethal contact.

\section{Physical Barriers}

Mirroring the safety concerns of some soil termiticide barriers, two physical barrier types, uniform-sized particles and stainless steel screening, have been employed as non-chemical controls in recent years. When used as continuous horizontal barriers installed during pre-construction installation, these physical barriers withstood intensive foraging activities of several termite species under field conditions (Su and Scheffrahn 1992, Lenz and Runko 1994). These non-chemical barriers are semi-permanent and can be readily installed during construction. Their physical presence, as opposed to the less visible chemical barriers, also provides ease for verification by regulatory inspectors.

\section{Population Control Using Baits}

Because a subterranean termite colony may contain 100,000 - 1,000,000 termites that forage up $150 \mathrm{ft}$, the soil termiticide application may not impact the overall colony population. In recent years, baits have become available for population control of subterranean termites. One such approach is the monitoring-baiting program that incorporates a bait matrix containing a chitin synthesis inhibitor, hexaflumuron, commercially known as the Sentricon ${ }^{\circledR}$ Termite Colony Elimination System. Stations containing a monitoring device are first installed in the soil around a home. When termites are found in the station, the monitoring device is replaced with a plastic tube containing the hexaflumuron-laced bait. Termites feeding in the stations then carry baits to other members of their colony, leading to the demise of the entire colony population. Details of the monitoring-baiting procedure can be found at http://flrec.ifas.ufl.edu/termite97.htm.

Numerous field studies with hexaflumuron baits have demonstrated that baited colonies of subterranean termites were eliminated ( $\mathrm{Su}$ and Scheffrahn 1998, Grace and Su 2001). Other baits (active ingredients) currently available include FirstLine ${ }^{\circledR}$ (sulfluramid), Exterra ${ }^{\circledR}$ (diflubenzuron), and Terminate ${ }^{\circledR}$ (sulfluramid). With the exception of Terminate ${ }^{\circledR}$ that can be purchased by individual homeowners, all baits are applied by trained pest control professionals. The efficacy and claims of these commercial bait products differ from one another, thus it is prudent to read the fine print and ask questions. For a review of some bait products, please refer to: http://www.uky.edu/Agri culture/Entomology/entfacts/struct/ef639.htm. 


\section{Selected References}

Grace J K, Su N-Y. 2001. Evidence supporting the use of termite baiting systems for long- term structural protection. Sociobiology 37: 301-310.

Lenz M, Runko S. 1994. Protection of buildings, other structures and materials in ground contact from attack by subterranean termites (Isoptera) with a physical barrier - a fine mesh of high- grade stainless steel. Sociobiology 24: 1-16.

Scheffrahn RH, Mangold JR, Su N-Y. 1988. A survey of structure-infesting termites of peninsular Florida. Florida Entomologist 71: 615-630.

Su N-Y, Scheffrahn RH. 1992. Penetration of sized-particle barriers by field populations of subterranean termites (Isoptera: Rhinotermitidae). Journal of Economic Entomology 85: 2275-2278.

Su N-Y, Ban PM, Scheffrahn, RH. 1993.

Foraging populations and territories of the eastern subterranean termite (Isoptera: Rhinotermitidae) in southeastern Florida. Environmental Entomology 22: 1113- 1117. 